\title{
Weight of school material and back pain in students leaving their books at school
}

\author{
Peso do material escolar e dor nas costas em alunos que deixam seus livros na escola \\ Denise de Melo-Marins ${ }^{1}$, Rodrigo Gustavo da Silva Carvalho', Lara Elena Gomes ${ }^{1}$
}

DOI 10.5935/1806-0013.20150056

\section{ABSTRACT}

BACKGROUND AND OBJECTIVES: The prevalence of back pain in children and adolescents has been reason for school health concern. Among different causes, school material weight is highlighted since studies have shown that it exceeds recommended values. So, strategies to decrease material weight have been adopted, such as the availability of cabinets or shelves to leave the books at school. However, it is not well explained whether such strategies would solve the problem. This study aimed at observing the association between school material weight and back pain in students who leave their material at school.

METHODS: Sample was made up of 48 students of the $5^{\text {th }}$ year of Basic Education of a municipal school of Petrolina-PE. Students and their materials were weighed. The back pain and body posture evaluation instrument was used to evaluate back pain.

RESULTS: Mean school material weight was $10.8 \pm 3.9 \%$ of body weight, without difference between genders. From 48 students, 20 have reported back pain and there has been no association between back pain and gender or school material weight.

CONCLUSION: Among students, $41.67 \%$ have reported back pain, while $52.09 \%$ carried weight above $10 \%$ of body weight, but there has been no association between school material weight and back pain.

Keywords: Back pain, Child, Load bearing.

\section{RESUMO}

JUSTIFICATIVA E OBJETIVOS: A prevalência de dor nas costas em crianças e adolescentes tem sido motivo de preocupaçōes no âmbito da saúde escolar. Entre as diferentes causas, o peso do material escolar destaca-se, uma vez que pesquisas mostram que este excede os valores recomendados. Assim, estratégias para reduzir o peso do material têm sido adotadas, como a disponibilidade de ar-

1. Universidade Federal do Vale do São Francisco, Petrolina, PE, Brasil.

Submitted in April 02, 2015.

Accepted for publication in October 22, 2015.

Conflict of interests: none - Sponsoring sources: Ministry of Education, Coordination of Graduated Personnel Enhancement and Tutorial Education Program.

\section{Correspondence to}

Lara Elena Gomes

Av. José de Sá Maniçoba, s/n - Centro

56304-205 Petrolina, PE, Brasil.

E-mail: lara.gomes@univasf.edu.br

(c) Sociedade Brasileira para o Estudo da Dor mários ou de estantes para deixar os livros na escola. Contudo, não está bem esclarecido se essas estratégias solucionam o problema. O objetivo deste estudo foi verificar a associaçáo entre o peso do material escolar e a presença de dor nas costas em alunos de uma escola, os quais deixam seus livros na escola.

MÉTODOS: A amostra foi composta por 48 alunos do $5^{\circ}$ ano do Ensino Fundamental de uma escola municipal de PetrolinaPE. Os alunos e seus materiais foram pesados. Para avaliar a presença de dor nas costas, foi utilizado o questionário de Avaliação da Postura Corporal e Dor nas Costas.

RESULTADOS: O peso médio do material escolar foi $10,8 \pm 3,9 \%$ do peso corporal, náo sendo encontrada diferença entre os gêneros. Dos 48 alunos, 20 relataram sentir dor nas costas e não foi encontrada associaçáo da presença de dor nas costas com o gênero e com o peso do material escolar.

CONCLUSÃO: Entre os alunos, 41,67\% relataram sentir dor nas costas, enquanto que $52,09 \%$ transportam um peso superior a $10 \%$ do peso corporal, mas não foi encontrada associação entre o peso do material escolar e a presença de dor nas costas.

Descritores: Criança, Dor nas costas, Suporte de carga.

\section{INTRODUCTION}

The prevalence of back pain in children and adolescents has been reason for school health concern. Several studies have shown the incidence of back pain in school children of different ages ${ }^{1-3}$, with some studies reporting higher pain prevalence among females ${ }^{4,5}$. Remaining for long periods in the sitting position, inadequate furniture, school material weight, as well as the way in which such material is carried and the model of backpacks, are associated to postural problems risks and to back pain among children and adolescents $s^{1,6-8}$.

It is during the school period that musculoskeletal system changes due to growth phase are more evidently present ${ }^{6,9}$. So, overloads imposed to such structures, especially to spine, increase the chances of developing postural changes ${ }^{10}$. Backpacks, for being the most practical and widely used way to carry school material ${ }^{6,11,12}$, have generated some concerns, since their weight and transportation are not always adequate, imposing disproportional overloads to such structures ${ }^{13}$.

Some authors suggest that the weight of school material should not exceed $10 \%$ of body weight ${ }^{6,8}$, while others admit that this value may reach $15 \%^{10,14}$. Some studies investigating the relationship between backpack weight and student weight, have observed that overload is present in more than $50 \%$ of cases ${ }^{14-16}$, being also reported that girls carry heavier 
weight than boys 5 .

Based on the above, strategies to decrease school material weight are already being adopted by some schools. The availability of cabinets favoring lower weight of school material carried by students has been one of such strategies. A study $y^{4}$, for example, has shown that students having access to cabinets had lower prevalence of back pain. However, it is still not clear whether such strategies really decrease the weight of carried school material and back pain.

So, this study aimed at observing the association between school material weight and back pain in students of a municipal school, who leave their books at school. Specific objectives where to check the association between back pain and gender and to compare school material weight between genders.

\section{METHODS}

To evaluate back pain, the Evaluation of Body Posture and Back Pain (BackPEI) questionnaire was used, since it has validity, content and reproducibility ${ }^{17}$. To evaluate body and school material mass, a digital scale (WISO, model W721; $0.1 \mathrm{~kg}$ resolution) and an analog scale (Feiticeira Ind. Utilid. Dom. Ltda; $0.0025 \mathrm{~kg}$ resolution) were used, respectively. When necessary, the digital scale was also used to check school material mass, since the analog scale had capacity for just $5 \mathrm{~kg}$. Since scales were from different brands, the accuracy of means was checked by plotting known and measured weights and establishing function linearity by means of determination coefficient, which was equal to 0.99 for both scales.

Since the school only allowed contact with students after the first teaching hour and in a single day of the week, data were collected in two interleaved moments during one week in the month of June 2013. In the first data collection day, the questionnaire was applied after a brief explanation about study procedures. Then, students were oriented to pack all materials. Next, both student and material were weighed. In the second data collection day, school material was again weighed aiming at observing reproducibility, since it was not possible to observe this variable in all days of the week. For our study, we considered question 18 of the BackPEI questionnaire $^{17}$, related to presence of back pain. School material weight was established as proportion of body weight of each student. So, this variable was defined by a simple rule of three, where students' weight represented $100 \%$.

Aiming at evaluating school material weight reproducibility, the normality of this variable obtained in the two data collection days was checked with Shapiro-Wilk test. Since normality was not achieved for the weight collected in the second day, reproducibility was evaluated by means of Wilcoxon test and Spearman correlation coefficient. From this, there has been association between school material weight evaluated in the two collection days $\left(r_{s}=0.53, p<0.001\right)$, and weights on both days were not different $(\mathrm{z}=-1.67, \mathrm{p}=0.095)$. So, weight evaluated in the first day was used for analysis. For data description, material weight mean and standard deviation were estimated and frequencies were established for the variable back pain, as well as frequencies were defined according to school material weight percentage (up to $10 \%$ and above $10 \%$ of body weight). A Boxplot was built considering school material weight and presence of back pain. Contingency tables were defined, and a Chi-square test was also conducted to check the association between back pain and school material weight and between gender and back pain. School material weight was also compared between genders with $t$ test for independent data and after confirming data normality with Shapiro-Wilk test and variance homogeneity by means of Levene test. All statistical tests were carried out with the software SPSS (version 17.0 for Windows), where significance level of 5\% was adopted. Statistical results are presented according to Field ${ }^{18}$ recommendations.

All guardians of students participating in the study were informed about data collection procedures and have authorized minors to participate in the study by signing the Free and Informed Consent Term (FICT).

This study was approved by the Ethics and Deontology in Studies and Research Committee, UNIVASF, under protocol 0013/270812, was authorized by the Municipal Department of Education of Petrolina-PE and is in compliance with the Declaration of Helsinki.

\section{RESULTS}

Sample was made up of 48 students of the $5^{\text {th }}$ year of Basic Education of a municipal school of Petrolina-PE (Table 1). Mean school material weight was $10.8 \pm 3.9 \%$ of body weight and there has been no difference between genders for this variable, $t(46)=-1.335, \mathrm{p}=0.188$. Figure 1 shows school material weight related to student's body weight and presence of back pain, being that from 48 students, 20 (41.7\%) have referred back pain (Table 2). There has been no association between back pain and gender $\chi^{2}(1)=0.002, p=0.96$, as shown in table 2.

From 48 students, 23 (47.91\%) carried weight up to $10 \%$ of body weight, and $25(52.09 \%)$ carried weight above this limit. Among those carrying weight up to $10 \%$ it was observed that $47.82 \%$ of students have referred back pain. For those with weight above $10 \%$ it was observed that $36 \%$ of students have referred back pain. There has been no association between relative school material weight and back pain, $\chi^{2}(1)=0.69, p=0.41$.

Table 1. Sample profile of a school from the city of Petrolina-PE, 2014

\begin{tabular}{lccc}
\hline & Age $(\text { years })^{*}$ & Mass $(\mathrm{kg})^{*}$ & Height $(\mathrm{m})^{*}$ \\
\hline $\begin{array}{l}\text { Males } \\
(\mathrm{n}=19)\end{array}$ & $10.60 \pm 0.63$ & $37.00 \pm 10.93$ & $1.41 \pm 0.08$ \\
$\begin{array}{l}\text { Females } \\
(\mathrm{n}=29)\end{array}$ & $10.64 \pm 0.74$ & $35.58 \pm 11.11$ & $1.43 \pm 0.08$ \\
Total $(\mathrm{n}=48)$ & $10.63 \pm 0.69$ & $36.15 \pm 10.94$ & $1.42 \pm 0.08$ \\
\hline *Values in Mean+SD & & &
\end{tabular}




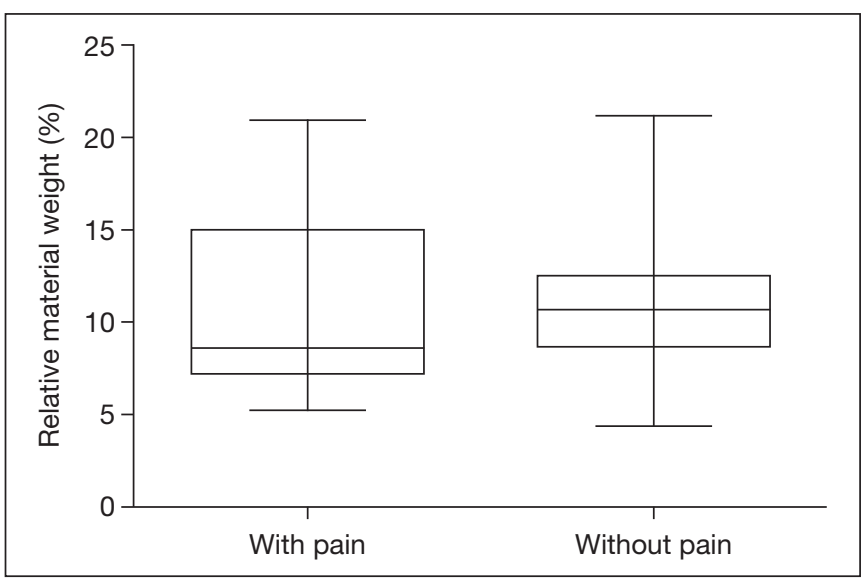

Figure 1. Boxplot: school material weight relative to body weight and presence of back pain.

Table 2. Percentage of students (number of students) according to back pain results

\begin{tabular}{lcc}
\hline & $\begin{array}{c}\text { With pain } \\
(\% \& n)\end{array}$ & $\begin{array}{c}\text { Without pain } \\
(\% \& n)\end{array}$ \\
\hline Males $(n=19)$ & $42.1(8)$ & $57.9(11)$ \\
Females $(n=29)$ & $41.4(12)$ & $58.6(17)$ \\
Total $(n=48)$ & $41.7(20)$ & $58.3(28)$ \\
\hline
\end{tabular}

\section{DISCUSSION}

Mean school material weight found in our study was $10.8 \%$ of body weight, being that $52.09 \%$ of students carried weight above $10 \%$. That is, it has been observed that more than half the students carried weight above recommended weight, confirming other studies findings ${ }^{14,16}$. Differently, Candotti, Noll $\&$ Roth $^{1}$ have found that just $31.8 \%$ of students of the $5^{\text {th }}$ year carried weight above $10 \%$.

There has been no difference between genders for carried weight. This finding is in line with López et al. ${ }^{19}$, who have studied students between 11 and 14 years of age and have found that mean school material weight was $13.4 \%$ and, although weight being above the recommended 10\%, there has been no association between school material weight and gender. Notwithstanding, Kellis \& Emmanouilidou ${ }^{5}$ have observed that girls carried heavier school material as compared to boys.

With regard to back pain, it was observed that $41.7 \%$ of students have reported back pain (Table 2). Farhood ${ }^{20}$ has evaluated low back pain in children between 6 and 12 years of age and has observed prevalence of $36.8 \%$. Saes et al. ${ }^{21}$ have evaluated factors associated to musculoskeletal pain in students from 6 to 18 years of age and have observed that $37.6 \%$ of students have reported pain in at least one investigated region, being reported, by $11 \%$ of students, pain in spinal dorsal region and by $10.9 \%$ in the lumbar region.

Similarly to López et al. ${ }^{19}$, we have not found difference in the presence of pain between genders (Table 2). Differently, other studies have observed that girls are more subject to back pain than boys. Noll et al. ${ }^{22}$ have shown pain prevalence of $48.7 \%$ and $60.1 \%$, respectively, for males and females. Martínez-Crespo et al. ${ }^{23}$ have also found higher prevalence of pain among females $(72.2 \%)$.

Our results have also not shown relationship between back pain and school material weight (Figure 1). This result confirms van Gent et al. ${ }^{15}$ who have evaluated 745 students between 12 and 14 years of age with relative school material weight of $14.70 \%$ and, similar to our results, have not found association between school material weight and back pain. Watson et al. ${ }^{24}$ have investigated the effect of mechanical and psychosocial factors in the prevalence of low back pain in students aged between 11 and 14 years. These authors have observed that the association of low back pain was related to psychosocial factors (emotional and behavioral), without relationship between low back pain and mechanical factors, such as school material weight, which is in line with our study.

Conversely, other studies have shown diverging results. Among them, Skaggs et al. ${ }^{4}$ have evaluated 1540 students with mean age of 12.4 years and have observed that $37 \%$ referred back pain. These authors have found association between school material weight and back pain. However, authors have observed that, among students having cabinets to keep school material, the presence of pain was lower. So, this measure might be a solution to decrease back pain associated to school material weight.

The availability of cabinets or shelves to leave school material at school was a justification for this study. But, in spite of this, material weight above $10 \%$ was found in more than half the sample $(52.09 \%)$. So, the strategy of leaving part of school material at school, as alternative to decrease school material weight, cannot be, alone, a strategy sufficient to revert this situation. This may show that, in addition to the already adopted strategy, there is the need for educative measures. Fernandes, Casarotto \& João ${ }^{7}$ have shown that educative sessions on the use of backpacks were able to decrease mean school material weight in $7 \%$. So, other measures seem to be necessary to decrease carried weight to prevent further overload and consequent back pain.

Lectures on healthy postural attitudes and physical education lessons focusing on flexibility, muscle resistance and body balance were conducted with students after data collection. In addition, students' guardians and teachers have received reports with the names of students deserving further attention. However, no evaluations were made after these interventions. This characterizes a limitation of our study, as well as the lack of comparison between the investigated school and a control school where students had no access to any strategy to decrease material weight.

So, the effect of leaving books at school or of having access to cabinets on school material weight decrease and whether this decrease is reflected also in less back pain are subjects needing to be further investigated. For example, it would be interesting to compare groups of students leaving part of material at school and others who need to carry all the material. Another investigation could be observing whether the implementation 
of one strategy (availability of cabinets or shelves) decreases school material weight and/or decreases the incidence of back pain, comparing before and after and longitudinally following up its effects. In addition, it is suggested that further studies are carried out in the Northeastern region of Brazil, since most studies are carried out in Southern and Southeastern regions, being this study a pioneer in the Northeastern region.

\section{CONCLUSION}

Our results have not shown association between school material weight and back pain in students of a municipal school of Petrolina-PE, as well as that there has been no effect of gender in the presence of back pain and school material weight. This results indicate the need for further studies to show the effect of strategies (such as access to cabinets or shelves) focusing on decreasing school material weight. It is also important to check whether this weight decrease implies less back pain prevalence.

\section{ACKNOWLEDGMENTS}

Authors would like to thank the board of the investigated school, the guardians of students participating in the study and all members of PET-Biomecânica, UNIVASF for their help in carrying out this work.

\section{REFERÊNCIAS}

1. Candotti CT, Noll M, Roth E. Avaliação do peso e do modo de transporte do material escolar em alunos do ensino fundamental. Rev Paul Pediatr. 2012;30(1):100-6.

2. Calvo-Muńoz I, Gómez-Conesa A. Asociación entre las mochilas escolares y el dolor de espalda. Revisión sistemática. Fisioterapia. 2012;34(1):31-8.

3. Sá CS, Carvalho RG, Gomes LE. Saúde escolar de crianças no ensino fundamental: avaliaçăo da prevalência de dor nas costas. Arq Ciênc Saúde. 2014;21(2):77-82.

4. Skaggs DL, Early SD, D'Ambra P, Tolo VT, Kay RM. Back pain and backpacks in school children. J Pediatr Orthop. 2006;26(3):358-63.

5. Kellis E, Emmanouilidou M. The effects of age and gender on the weight and use of schoolbags. Pediatr Phys Ther. 2010;22(1):17-25.

6. Rodrigues S, Montebelo MI, Teodori RM. Distribuição da força plantar e oscilação do centro de pressão em relaçáo ao peso e posicionamento do material escolar. Rev Bras Fisioter. 2008;12(1):43-8.

7. Fernandes SM, Casarotto RA, João SM. Efeitos de sessōes educativas no uso das mochilas escolares em estudantes do ensino fundamental I. Rev Bras Fisioter. 2008;12(6):38-44

8. Benini J, Karolczak AP. Benefícios de um programa de educação postural para alunos de uma escola municipal de Garibaldi, RS. Fisioter Pesq. 2010;17(4):346-51.

9. Milbradt SN, Pranke GI, Texeira CS, Lemos LF, Alves RF, Mota CB. Aspectos da coluna vertebral relacionados à postura em crianças e adolescentes em idade escolar. Fisioter Bras. 2011;12(2):127-32.

10. Brackley HM, Stevenson JM. Are children's backpack weight limits enough? A critical review of the relevant literature. Spine. 2004;29(19):2184-90.

11. Brackley HM, Stevenson JM, Selinger JC. Effect of backpack load placement on posture and spinal curvature in prepubescent children. Work. 2009;32(3):351-60.

12. Ritter AL, Souza JL. Transporte do material escolar por escolares da rede municipal de ensino fundamental de Porto Alegre-RS. R Bras Ci Mov. 2011;19(4):51-9.

13. Ries LG, Martinello M, Medeiros M, Cardoso M, Santos GM. Os efeitos de diferentes pesos de mochila no alinhamento postural de crianças em idade escolar. Motri. 2012;8(4):87-95.

14. Negrini S, Carabalona R, Sibilla P. Backpack as a daily load for schoolchildren. Lancet. 1999;354(9194):1974.

15. van Gent C, Dols JJ, de Rover CM, Hira Sing RA, de Vet HC. The weight of schoolbags and the occurrence of neck, shoulder, and back pain in young adolescents. Spine. 2003;28(9):916-21.

16. Al-Hazzaa HM. School backpack. How much load do Saudi school boys carry on their shoulders? Saudi Med J. 2006;27(10):1567-71.

17. Noll M, Candotti CT, Vieira A, Loss JF. Back pain and body posture evaluation instrument (BackPEI): development, content validation and reproducibility. Int J Public Health. 2013;58(4):565-72.

18. Field A. Discovering statistics using SPSS. $3^{\text {rd }}$ ed. London: SAGE Publications Ltd 2009.

19. López SA, García IP, Alonso IC, Garcinuño AC, de Llano JM. Mochilas escolares y dolor de espalda en la población infantil. Rev Pediatr Aten Primaria. 2010;12(47):38597.

20. Farhood HF. Low back pain in schoolchildren: the role of school bag weight and carrying way. J Nat Sci Res. 2013;3(8):156-64.

21. Saes MO, Soares MD, Mucillo-Baisch A, Soares MC. Fatores associados à dor musculoesquelética em escolares da rede pública municipal no extremo sul do Brasil. Rev Bras Saúde Matern Infant. 2014;14(3):211-8.

22. Noll M, Candotti CT, Tiggemann CL, Schoenell MCW, Vieira A. Prevalência de dor nas costas e fatores associados em escolares do Ensino Fundamental do município de Teutônia, Rio Grande do Sul. Rev Bras Saúde Matern Infant. 2012;12(4):395-402.

23. Martínez-Crespo G, Rodríguez-Piñero DM, López-Salguero AI, Zarco-Periñan MJ, Ibánez-Campos T, Echevarría-Ruiz de Vargas YC. Dolor de espalda en adolescentes: prevalencia y factores asociados. Rehabilitación. 2009;43(2):72-80.

24. Watson KD, Papageorgiou AC, Jones GT, Taylor S, Symmons DP, Silman AJ, et al. Low back pain in schoolchildren: the role of mechanical and psychosocial factors. Arch Dis Child. 2003;88(1):12-7. 